\title{
Recurrence-Free Survival Stage IB1-IIA2 Intermediate Risk Group (Based on Kartu Delgado) Cervical Carcinoma after Radical Surgery and Adjuvant Radiotherapy
}

\author{
Kesintasan Bebas Kekambuhan Kelompok Risiko Menengah Berdasarkan \\ Kartu Delgado pada Kanker Serviks Stadium IB1-IIA2 \\ Pascaoperasi Radikal dan Radioterapi Ajuvan
}

\author{
Andi Friadi' ${ }^{1}$, Sigit Purbadi ${ }^{2}$, Budiningsih Siregar ${ }^{3}$, Bambang Sutrisna ${ }^{4}$ \\ ${ }^{1}$ Division of Gynecologic Oncology \\ Department of Obstetrics and Gynecology \\ Faculty of Medicine Andalas University \\ Padang \\ ${ }^{2}$ Division of Gynecologic Oncology \\ Department of Obstetrics and Gynecology \\ ${ }^{3}$ Department of Anatomical Pathology \\ ${ }^{4}$ Department of Public Health \\ Faculty of Medicine Indonesia University \\ Jakarta
}

\begin{abstract}
Objective: To evaluate the benefits of adjuvant radiotherapy (ART) based on Kartu Delgado (simple form of Gynecologic Oncology Group (GOG) scoring system) aimed at women with early stage cervical cancer after radical surgery.

Method: Fifty patients were enrolled for this study. Twenty one patients from 2011-2012 were given ART following surgery based on their Kartu Delgado score from as follows: score $<120$ were designated for observation; score $>120$ were given ART. Their score and recurrence were compared with 29 patients who were treated in 2009-2010 (based on single prognostic factor).

Result: We observed eighteen recurrences for the duration this study. Thirteen patients from the period of 2009-2010 and five patients from the period of 2011-2012. Most recurrences occurred in patients from 2009-2010 with score > 120 but were not designated ART. Two-years recurrence-free survival (RFS) for subjects with score $<120$ who were designated observation was $76.23 \%$ while for score $>120$ with ART was $64.29 \%$.
\end{abstract}

Conclusion: Adjuvant radiotherapy given based on Kartu Delgado reduced the number of recurrences in women with stage IB-IIA cervical cancer after treated by surgery.

[Indones J Obstet Gynecol 2014; 3: 146-152]

Keywords: cervical carcinoma, intermediate risk, prognostic factor, radical hysterectomy

\begin{abstract}
Abstrak
Tujuan: Mengevaluasi manfaat pemberian radiasi ajuvan yang berbasiskan Kartu Delgado pada pasien kanker serviks stadium dini pascapembedahan.

Metode: Lima puluh pasien diikutsertakan dalam penelitian ini. Dua puluh satu pasien menerima radiasi ajuvan pascapembedahan berdasarkan skor yang didapat dengan ketentuan sebagai berikut: skor $<120$ pasien diobservasi sedangkan skor >120 maka pasien diberi radiasi ajuvan. Skor dan kekambuhannya dibandingkan dengan $29 \mathrm{ka}-$ sus dari periode 2009-2010 yang ditatalaksana berbasiskan satu faktor prognostik
\end{abstract}

Hasil: Delapan belas kekambuhan terjadi pada penelitian ini. Tiga belas pasien yang mengalami kekambuhan berasal dari periode 2009-2010 dan lima pasien kambuh berasal dari periode 2011-2012. Kekambuhan tertinggi (50\%) berasal dari periode 2009-2010 pada pasien dengan skor $>120$ tetapi tidak dilakukan radiasi ajuvan. Kesintasan 2-tahun bebas kekambuhan pada skor $<120$ di mana dilakukan observasi adalah 76,23\% sedangkan kesintasan 2-tahun bebas kekambuhan untuk skor $>120$ di mana diberikan radioterapi ajuvan adalah 64,29\%.

Kesimpulan: Pemberian radioterapi ajuvan berdasarkan Kartu Delgado mengurangi kekambuhan pada pasien kanker serviks stadium IB-IIA pascapembedahan.

[Maj Obstet Ginekol Indones 2014; 3: 146-152]

Kata kunci: faktor prognostik, histerektomi radikal, kanker serviks, risiko menengah

Correspondence: Andi Friadi. Division of Gynecologic Oncology Department of Obstetrics and Gynecology Faculty of Medicine University of Andalas/M Djamil Hospital. Jln. Perintis Kemerdekaan, Padang, Indonesia.

Telephone: 085263076356, E-mail: andi_friadi@yahoo.com

\section{INTRODUCTION}

Traditionally, the risk group of early stages (stage IB-IIA) cervical cancer after radical hysterectomy
(RH) and pelvic lymph node dissection (PLND) is divided into two based on the prognostic factors associated with the risk of recurrence which is 
high-risk groups (with lymph nodes metastases (LNM)) and non-high-risk groups (without LNM). Previously, adjuvant radiotherapy (ART) is only indicated for high-risk groups. Next is non-high-risk groups (without LNM) where the name is later changed into intermediate-risk group. ${ }^{1}$ The problems arising in the intermediate-risk group who do not receive ART is the presence of recurrence. On the other hand, there are difficulties in determining the intermediate-risk group requiring ART, whether only one prognostic factor is enough as an indication for ART or a combination of prognostic factors is needed.

In its recent definition, high-risk group is not limited only to cases with LNM but also parametrial invasion and positive surgical margin. ${ }^{2}$ Sedlis et al introduced the term intermediate-risk and utilized three prognostic factors, namely lymphovascular space invasion (LVSI), tumor size and depth of stromal invasion (DSI). ${ }^{1}$ Gynecologic Oncology Group (GOG) pioneered by Delgado et al combined those three factors and make the GOG scoring system. They found that a score higher than 120 without ART correlated with a $41 \%$ recurrence rate. ${ }^{3}$ Rushdan et al reported that a score higher than 120 after ART showed a recurrence rate of $7.1 \%$ ( 1 out of 14 patients). ${ }^{4}$

Controversy on the indication of ART occurs due to a lack of standardization criteria for receiving ART. Research on the assessment of cervical cancer prognostic factor and the role of ART on cervical cancer patients provided varying results in each oncology centers. These results are difficult to compare because of differences in patient selection.

This is our first experience to determine if there is an improvement in outcome when the indication for ART is based on Kartu Delgado (simple form of GOG scoring system). Thus, the aim of this study is to evaluate the treatment outcomes and confirm the applicability of combination prognostic factor (Kartu Delgado) instead of single prognostic factor as indication for ART.

\section{METHODS}

This study was approved by the Institutional Ethics Committee of Universitas Indonesia, dr. Cipto Mangunkusumo hospital, Jakarta. We enrolled 50 patients with stage IB1 to IIA2 intermediate-risk group cervical cancer post-RH and PLND during the period of January 2009 until December 2012. Patients with histopathological findings that showed negative LNM, negative parametrial invasion and clear surgical margins were included in the study. Patients with neuroendocrine histopathology and cervical cancer patients accompanied by presence of other cancer were excluded from the study. Design used in this study was ambispective cohort. We observed the 2009-2010 period with a historical cohort design (ART designation based on single prognostic factor) and the period of 20112012 with a prospective cohort design (ART designation based on Kartu Delgado). For period of January 2009 until December 2010, medical records were reviewed retrospectively and the following parameters were collected: FIGO stage, tumor size, DSI, LVSI, adjuvant treatment, date of surgery and date of recurence or last follow-up.

Depth of stromal invasion was measured in millimeters and fractional thickness of the cervix divided into thirds (superficial, middle and deep). ${ }^{3}$ DSI was measured as the maximum perpendicular distance from the basement membrane to the outer tumor surface. ${ }^{5}$ DSI measurement was taken from the base of the epithelium from which the carcinoma arises to the deepest point of invasion. ${ }^{6,7}$ For tumor size, we measured the greatest diameter of the tumor on the postoperative specimen before it was preserved with formaldehyde. ${ }^{8}$ LVSI was considered positive when neoplastic cells were seen within endothelium-lined spaces. $3,5,9$

All slides were re-evaluated using hematoxylin and eosin (H\&E) staining to analyze DSI and LVSI by expert pathologist. Subsequently, the score was calculated using Kartu Delgado (Figure. 1). Firstly, we circle the size of the tumor and the LVSI status then pull a downward line. Next, the number corresponding to the DSI is circled and a horizontal line is drawn from there. The intersect of these two lines is the score. Patients with a score higher than 120 were given ART while patients with a score lower than 120 were not given ART and only observed.

All designated patient treatment were approved by our tumor board, and patients also provided written informed consent. Adjuvant radioterapy was given in the form of external beam radiotherapy (EBRT) alone started within four weeks after surgery. EBRT was delivered to the whole pelvis 
KARTU DELGADO

(adapted fiom GOG score)

\begin{tabular}{|c|c|c|c|c|c|c|c|c|c|c|c|c|c|}
\hline \multirow{3}{*}{$\begin{array}{l}\text { Depth of } \\
\text { stromal } \\
\text { invasion } \\
\text { (mm) }\end{array}$} & \multicolumn{13}{|c|}{ Tumor size $(\mathrm{cm})+$ IVSI $(+/-)$} \\
\hline & \multicolumn{2}{|c|}{$1 \mathrm{~cm}$} & \multicolumn{2}{|c|}{$2 \mathrm{~cm}$} & \multicolumn{2}{|c|}{$3 \mathrm{~cm}$} & \multicolumn{3}{|c|}{$4 \mathrm{~cm}$} & \multicolumn{2}{|c|}{$6 \mathrm{~cm}$} & \multicolumn{2}{|c|}{$8 \mathrm{~cm}$} \\
\hline & - & + & - & + & - & + & 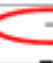 & $=$ & + & - & + & - & + \\
\hline \multicolumn{14}{|l|}{ Superficial } \\
\hline $3 \mathrm{~mm}$ & 1,6 & 2,7 & 1,9 & 3,2 & 2,4 & 4,1 & 2 & 9 & 4,9 & 4,4 & 7.5 & 6,6 & 11,2 \\
\hline $4 \mathrm{~mm}$ & 4,8 & 8,2 & 5,7 & 9.7 & 7,2 & 12,2 & s & 7 & 14,8 & 13,2 & 22,4 & 19,8 & 33,7 \\
\hline $5 \mathrm{~mm}$ & 11,5 & 19,6 & 13,7 & 23,2 & 17,2 & 29,4 & 2 & 9 & 35,5 & 31,7 & 53,8 & 47,5 & 80,8 \\
\hline $6 \mathrm{~mm}$ & 22,4 & 38,1 & 26,6 & 45,2 & 33,6 & 57,1 & 4 & .6 & 69,0 & 61,6 & 104,7 & 92,4 & 154,1 \\
\hline $7 \mathrm{~mm}$ & 33,6 & 57,1 & 39,9 & 67,8 & 50,4 & 85,7 & 6 & 9 & 103,5 & 92,4 & 157,1 & 138,6 & 235,6 \\
\hline $8 \mathrm{~mm}$ & 41,6 & 70,7 & 49,4 & 83,9 & 62,4 & 106,1 & 7 & 4 & 128,2 & 114,4 & 194,5 & 171,6 & 291,7 \\
\hline $10 \mathrm{~mm}$ & 33,6 & 57,1 & 39,9 & 67,8 & 50,4 & 85,7 & 6 & 9 & 103,5 & 92,4 & 157,1 & 138,6 & 235,6 \\
\hline \multicolumn{14}{|l|}{ Middle } \\
\hline $5 \mathrm{~mm}$ & 32 & 54,4 & 38 & 64,6 & 48 & 81,6 & 4 & 8 & 98,6 & 88 & 149,6 & 132 & 224,4 \\
\hline $6 \mathrm{~mm}$ & 35,2 & 59,8 & 41,8 & 71,1 & 52,8 & 89,8 & 6. & -8 & 108,5 & 96,8 & 164,6 & 145,2 & 246,8 \\
\hline $7 \mathrm{~mm}$ & 36,8 & 62,6 & 43,7 & 74,3 & 55,2 & 93,8 & 6 & .7 & 113,4 & 101.2 & 172,0 & 151,8 & 258,1 \\
\hline $8 \mathrm{~mm}$ & 40 & 68 & 47,5 & 80,7 & 60 & 102 & 7 & 5 & 123,2 & 110 & 187 & 165 & 280,5 \\
\hline $10 \mathrm{~mm}$ & 44,8 & 76.2 & 53,2 & 90,4 & 67,2 & 114,2 & 8 & 2 & 138,0 & 123,2 & 209,4 & 184,8 & 314,2 \\
\hline $12 \mathrm{~mm}$ & 51,2 & 87,0 & 60,8 & 103,4 & 76,8 & 130,6 & 9 & -8 & 157,8 & 140,8 & 239,4 & 211,2 & 359,0 \\
\hline $14 \mathrm{~mm}$ & 57,6 & 97,9 & 68,4 & 116,3 & 86,4 & 146,9 & 10 & 4,4 & 177,5 & 158,4 & 269,3 & 237,6 & 403,9 \\
\hline \multicolumn{14}{|l|}{ Deep } \\
\hline $7 \mathrm{~mm}$ & 44,8 & 76,2 & 53,2 & 90,4 & 67,2 & 114,2 & 8 & .2 & 138,0 & 123,2 & 209,4 & 184,8 & 314,2 \\
\hline $8 \mathrm{~mm}$ & 48 & 81,6 & 57 & 96,9 & 72 & 122,4 & & 7 & 147,9 & 132 & 224,4 & 198 & 336,6 \\
\hline $10 \mathrm{~mm}$ & 54,4 & 92,5 & 64,6 & 109,8 & 81,6 & 138,7 & 2 & 6 & 167,6 & 167,6 & 254,3 & 224,4 & 381,5 \\
\hline $12 \mathrm{~mm}$ & 59,2 & 100,6 & 70,3 & 119,5 & 88,8 & 150,9 & 1. & 8,3 & 182,4 & 182,4 & 276,8 & 244,2 & 415,1 \\
\hline $14 \mathrm{~mm}$ & $=$ & & & 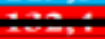 & & $\because-6$ & $11:$ & 8,9 & 202,1 & 202,1 & 306,7 & 270,6 & 460,0 \\
\hline $16 \mathrm{~mm}$ & 72 & 122,4 & 85,5 & 145,3 & 108 & 183,6 & 131 & 0,5 & 221,8 & 221,8 & 336,6 & 297 & 504,9 \\
\hline $18 \mathrm{~mm}$ & 78,4 & 133,3 & 93,1 & 158,3 & 117,6 & 199,9 & 14 & 2,1 & 241,6 & 241,6 & 366,5 & 323,4 & 549,8 \\
\hline $20 \mathrm{~mm}$ & 86,4 & 146,8 & 102,6 & 174,4 & 129,6 & 220,3 & 15 & 6,6 & 266,2 & 266,2 & 403,9 & 356,4 & 605,9 \\
\hline
\end{tabular}

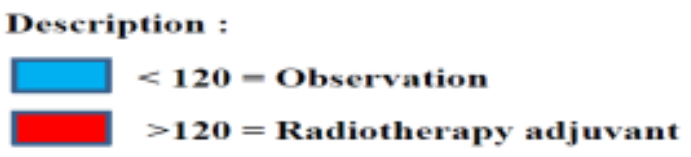

The requirements :

NO lymph nodes metastasis

NO parametrial invasion

Negative surgical margin

Figure 1. How to Use Kartu Delgado.

(standard field) in 2.00 Gy fractions once daily for 5 days per week. At the time of follow-up, patients were categorized as no evidence of disease if there were no suspicion of recurrence. ${ }^{10}$ Patients were evaluated by anamnesis, pelvic and bimanual examination, and ultrasonography every three months during the first two years of follow-up. Patients who did not come for follow up, were contacted via telephone to come for follow up. ${ }^{11}$

All data was stored using Microsoft Excel and the statistical analyses performed using Stata version 12. Bivariate analyses were calculated using Pearson's chi-square and Fisher's exact test. Probability was considered significant if $p$ value $<0,05$ with confidence interval $95 \%$. Correlation between Kartu Delgado score and recurrence-free interval (RFI) were evaluated with Pearson correlation test. Recurrence-free survival (RFS) was calculated from the date of surgery to recurrence or the latest date of follow-up using Kaplan Meier. Survival differences were tested by the log rank test.

\section{RESULTS}

During the research period there were 18 cases of recurrences. During the 2009-2010 period, indication for ART is only based on single prognostic factor (moderate-poor differentiation, adenocarcinoma type, positive LVSI and large tumor size) and there were thirteen cases $(72.22 \%)$ of recurrence. During the period of 2011-2012, ART was designated based on Kartu Delgado and five (27.78\%) cases of recurrence were identified. The clinicopathologic characteristics of intermediate-risk group are summarized in Table 1 . Ten cases of recurrence, occurred at score of more than 120 managed with observation ( 8 cases from the $2009-2010$ period). 
Table 1. Baseline Characteristics of Intermediate-Risk Group.

\begin{tabular}{|c|c|c|c|c|}
\hline \multirow{2}{*}{ Characteristic } & & \multicolumn{2}{|c|}{ Event of recurrence $(n=50)$} & \multirow[b]{2}{*}{$\begin{array}{l}\text { Univariate } \\
\text { p-value }\end{array}$} \\
\hline & & $\begin{array}{l}\text { NED } \\
32(100 \%)\end{array}$ & $\begin{array}{l}\text { Recurrence } \\
18(100 \%)\end{array}$ & \\
\hline $\begin{array}{l}\text { Stage } \\
\text { (FIGO 2009) }\end{array}$ & $\begin{array}{l}\text { IB1 } \\
\text { IB2 } \\
\text { IIA1 } \\
\text { IIA2 }\end{array}$ & $\begin{array}{c}25(78.13 \%) \\
1(3.13 \%) \\
5(15.63 \%) \\
1(3.13 \%)\end{array}$ & $\begin{array}{c}7(38.89 \%) \\
7(38.89 \%) \\
4(22.22 \%) \\
0(0 \%)\end{array}$ & 0.005 \\
\hline Kartu Delgado score & $\begin{array}{l}<120 \\
>120\end{array}$ & $\begin{array}{c}23(71.88 \%) \\
9(28.13 \%)\end{array}$ & $\begin{array}{c}6(33.33 \%) \\
12(66.67 \%)\end{array}$ & 0.008 \\
\hline Histologic subtype & $\begin{array}{c}\text { Squamous cell carcinoma (SCC) } \\
\text { Adenocarcinoma } \\
\text { Adenosquamous carcinoma }\end{array}$ & $\begin{array}{r}21(65.63 \%) \\
7(21.88 \%) \\
4(12.50 \%)\end{array}$ & $\begin{array}{c}10(55.56 \%) \\
7(38.89 \%) \\
1(5.56 \%)\end{array}$ & 0.380 \\
\hline Tumor size & 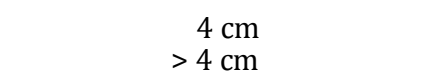 & $\begin{array}{c}30(93.75 \%) \\
2(6.25 \%)\end{array}$ & $\begin{array}{c}11(61.11 \%) \\
7(38.89 \%)\end{array}$ & 0.004 \\
\hline LVSI & $\begin{array}{l}\text { Negative } \\
\text { Positive }\end{array}$ & $\begin{array}{l}22(68.75 \%) \\
10(31.25 \%)\end{array}$ & $\begin{array}{c}12(66.67 \%) \\
6(33.33 \%)\end{array}$ & 0.880 \\
\hline Differentiation & $\begin{array}{l}\text { Well } \\
\text { Moderate } \\
\text { Poor }\end{array}$ & $\begin{array}{c}7(21.88 \%) \\
19(59.38 \%) \\
6(18.75 \%)\end{array}$ & $\begin{array}{c}2(11.11 \%) \\
13(72.22 \%) \\
3(16.67 \%)\end{array}$ & 0.587 \\
\hline Adjuvant Treatment & $\begin{array}{c}\text { Observation } \\
\text { Adjuvant Radiotherapy }\end{array}$ & $\begin{array}{l}24(75 \%) \\
8(25 \%)\end{array}$ & $\begin{array}{l}16(88.89 \%) \\
2(11.11 \%)\end{array}$ & 0.239 \\
\hline Period & $\begin{array}{l}2009-2010 \\
2011-2012\end{array}$ & $\begin{array}{l}14(43.75 \%) \\
18(56.25 \%)\end{array}$ & $\begin{array}{c}13(72.22 \%) \\
5(27.78 \%)\end{array}$ & 0.053 \\
\hline
\end{tabular}

NED = no evidence of disease

Among the clinicopathologic factors analyzed in this study, only Kartu Delgado is significantly related to recurrence. Bivariate analysis revealed that Kartu Delgado provided a risk ratio (RR) of 2.91, with 95\% confidence interval (CI) 1.43 to 5.90 and $\mathrm{p}=0.003$. No significant relation was identified between recurrence and tumor size, LVSI, histologic subtype, and differentiation as a single prognostic factor. Relation of clinicopathologic factors as single prognostic factor and combination prognostic factor is presented in Table 2. The management given to the patients may be consistent or inconsistent with the management indicated by the prognostic factors, as indicated in Table 2.

To determine the correlation between Kartu Delgado scores with RFI, we created a scatterplot (Figure. 2) and analyzed using a Pearson correla- tion test ( $\mathrm{p}=0.0003)$. The correlation was found to be negative, meaning the higher the score, RFI will be declined.

Our data showed survival between 2009-2010 period and 2011-2012 period, an estimated twoyears RFS of single prognostic factor was $55.56 \%$ and by using Kartu Delgado was $77.5 \%$. Survival between a score $<120$ and score $>120$, an estimated 2-years RFS for score $>120$ was $43.78 \%$, while for score $<120$ was $78.03 \%$. Survival of each management as assigned using Kartu Delgado could be stratified into four groups, as seen in Figure 3. The estimated 2-years RFS for score $<120$ with ART was $100 \%, 76.23 \%$ for score $<120$ with observation, $64.29 \%$ for score $>120$ with ART and $30.77 \%$ for score $>120$ with observation. 
Table 2. Bivariate Analysis of Clinicopathologic Factor (Kartu Delgado vs Single Prognostic Factor) Related to Recurrence.

\begin{tabular}{|c|c|c|c|c|c|c|}
\hline \multirow{2}{*}{$\begin{array}{c}\text { Clinicopathologic } \\
\text { Factor (Management) }\end{array}$} & \multicolumn{2}{|c|}{ Event of recurrence } & \multirow[t]{2}{*}{ Total } & \multirow{2}{*}{$\mathbf{p}$} & \multirow{2}{*}{$\mathbf{R R}$} & \multirow{2}{*}{ 95\%CI } \\
\hline & $\begin{array}{l}\text { NED } \\
\text { n (\%) }\end{array}$ & $\begin{array}{l}\text { Recurrence } \\
\text { n (\%) }\end{array}$ & & & & \\
\hline $\begin{array}{l}\text { Consistent Kartu Delgado } \\
\text { Score }<120 \text { (Observation) } \\
\text { Score }>120 \text { (ART) }\end{array}$ & $27(77.14 \%)$ & 8 (22.86\%) & $35(100 \%)$ & 0.003 & 2.91 & $1.43-5.90$ \\
\hline $\begin{array}{l}\text { Inconsistent Kartu Delgado } \\
\text { Score }<120 \text { (ART) } \\
\text { Score }>120 \text { (Observation) }\end{array}$ & $5(33.33 \%)$ & $10(66.67 \%)$ & $15(100 \%)$ & & & \\
\hline $\begin{array}{l}\text { Consistent single prognostic factor (tumor size) } \\
<4 \mathrm{~cm} \text { (Observation) } \\
>4 \mathrm{~cm}(\mathrm{ART})\end{array}$ & $24(68.57 \%)$ & $11(31.43 \%)$ & $35(100 \%)$ & 0.304 & 1.48 & $0.71-3.07$ \\
\hline $\begin{array}{l}\text { Inconsistent single prognostic factor } \\
<4 \mathrm{~cm} \text { (ART) } \\
>4 \mathrm{~cm} \text { (Observation) }\end{array}$ & $8(53.33 \%)$ & 7 (46.67\%) & $15(100 \%)$ & & & \\
\hline $\begin{array}{l}\text { Consistent single prognostic factor (LVSI) } \\
\text { LVSI negative (Observation) } \\
\text { LVSI positive (ART) }\end{array}$ & $24(66.67 \%)$ & $12(33.33 \%)$ & $36(100 \%)$ & 0.529 & 1.28 & $0.60-2.75$ \\
\hline $\begin{array}{l}\text { Inconsistent single prognostic factor } \\
\text { LVSI negative (ART) } \\
\text { LVSI positive (Observation) }\end{array}$ & 8 (57.14\%) & $6(42.86 \%)$ & $14(100 \%)$ & & & \\
\hline $\begin{array}{l}\text { Consistent single prognostic factor } \\
\text { (Histologic subtype) } \\
\text { SCC (Observation) } \\
\text { Non SCC (ART) }\end{array}$ & $15(60 \%)$ & $10(40 \%)$ & $25(100 \%)$ & 0.556 & 0.80 & $0.37-1.68$ \\
\hline $\begin{array}{l}\text { Inconsistent single prognostic factor } \\
\text { SCC (ART) } \\
\text { Non SCC (Observation) }\end{array}$ & $17(68 \%)$ & $8(32 \%)$ & $25(100 \%)$ & & & \\
\hline $\begin{array}{l}\text { Consistent single prognostic factor } \\
\text { (Differentiation) } \\
\text { Well-Moderate (Observation) } \\
\text { Poor (ART) }\end{array}$ & $24(61.54 \%)$ & $15(38.46 \%)$ & $39(100 \%)$ & $0.72^{*}$ & 0.70 & $0.24-2.01$ \\
\hline $\begin{array}{l}\text { Inconsistent single prognostic factor } \\
\text { Well-Moderate (ART) } \\
\text { Poor (Observation) }\end{array}$ & $8(72.73 \%)$ & $3(27.27 \%)$ & $11(100 \%)$ & & & \\
\hline
\end{tabular}

${ }^{*}$ Fisher exact

$A R T=$ Adjuvant Radiotherapy; SCC=squamous cell carcinoma; LVSI=lymphovascular space invasion; RR=risk ratio

$N E D=$ no evidence of disease

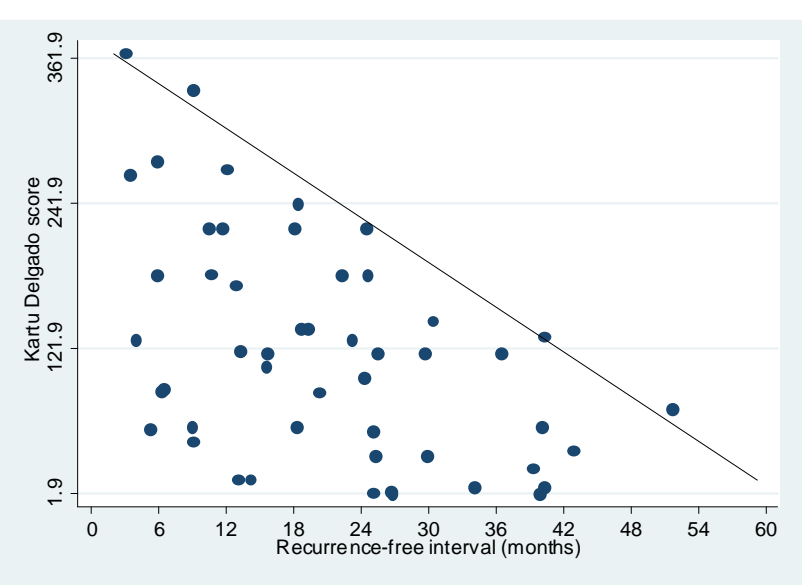

Figure 2. Correlation of Kartu Delgado score with RFI.

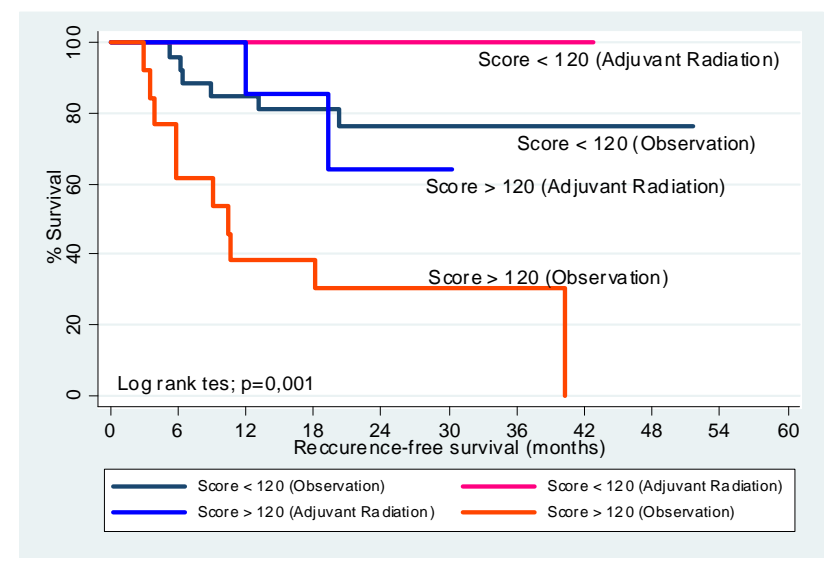

Figure 3. Survival Based on Kartu Delgado and Management. 


\section{DISCUSSION}

The purpose of this study is to evaluate recurrence among intermediate-risk stage IB-IIA cervical cancer after RH and PLND with application of Kartu Delgado as indication for ART. This study answers the question whether single factor prognostic is reliable as indication for ART or a combination of prognostic factors is required. In this study we combined three prognostic factors, namely DSI, tumor size and LVSI. We were able to demonstrate that the use of single prognostic factor as indication of ART has weaknesses in predicting the recurrence. For example in cases with negative LVSI, DSI and tumor size as prognostic factors actually have an important role in determining whether ART is required or not. This is clearly seen in the scoring system of Kartu Delgado where each prognostic factor plays a role in determining the score and each patient has her own score, although they are at the same stage (IB-IIA). Perhaps, this will explain the difference in survival among intermediate-risk groups.

In this study, we discovered that Kartu Delgado score is significantly related $(\mathrm{p}=0.003)$ with recurrence. Delgado et al reported that score $>120$ and managed with observation is related to a recurrence rate of $41 \%{ }^{3}$ Our data showed that score $>120$ managed with observation only is related to a recurrence rate of $76.9 \%$. Meanwhile when patients scoring $>120$ was managed with ART the recurrence rate was reduced by $51.9 \%$ to $25 \%$. Eventhough there are no recurrences in patients with score $<120$ assigned to ART, it should be noted that their actual score were less than 40 (these patients were given ART due to poor diferentiation and non-SCC histologic subtype). Rushdan et al and Yeo et al found that for cases with scores less than 40 with observation there were also no recurrences. ${ }^{4,11}$

We found the correlation between Kartu Delgado score with RFI to be clinically and statistically significant $(p=0.0003)$. To our knowledge, this is the first report showing a significant correlation of a scoring system with RFI. We also observed no relationship between the large tumor size, positive LVSI, moderate-poor differentiation and adenocarcinoma type histopathology as a single prognostic factor for recurrence. Use of a single prognostic factor as indication for ART is not able to predict recurrence.

Our results were similar with several other stud- ies. Rutledge et al stated that cervical cancer prognosis is affected by LVSI and DSI, not just tumor size as the criteria to determine stage IB1 and IB2. ${ }^{12}$ A surgical approach to stratify patients' risk based on surgical-pathologic information such as LVSI and DSI would seem to be a reasonable treatment approach. Memarzadeh et al reported that presence of LVSI alone was not a predictor of pelvic nodal disease. ${ }^{13}$ Cervical LVSI in combination with parametrial LVSI was predictive of metastatic disease $(p<0.001)$. Depth of invasion within the cervical stroma was associated with parametrial LVSI. It was concluded that LVSI and DSI in combination is prognostic for LNM. Zaino et al reported that degree of differentiation as a prognostic factor cannot stand alone. ${ }^{14}$ Its combination with DSI and LVSI is essential and should be reported routinely. At the early stages of cervical cancer there is no significant difference in survival between squamous cell carcinoma and adenocarcinoma. Ayhan et al added that histopathologic type is not a prognostic factor for early stage cervical cancer with no reported LNM. ${ }^{15}$

Most recurrence of cervical cancer occurs within the first two years after surgery. ${ }^{16}$ Monk et al reported that recurrence within 24 months after surgery is as high as $88 \% .{ }^{17}$ Likewise, Reis et al observed the rate of recurrence within 24 months after $\mathrm{RH}$ to be about $89 \% .{ }^{18}$ Pieterse et al found a lower recurrence rate of about $63 \%$ within 24 months post-surgery. ${ }^{19}$

Samlal et al found that patients without LNM has a 5-year survival rate of around $90 \%$, compared to $50 \%-65 \%$ in patients with LNM. ${ }^{20}$ Our study obtained a survival rate of $30.77 \%$ in patients who should have received ART (score $>120$ ) but did not receive ART. Survival rate was found to reach $64.29 \%$ when high-risk group with a score $>120$ received ART. For the intermediate-risk group with a score $<120$ managed with observation only, the survival rate was $76.23 \%$. The difference in survival rate in our study with Samlal et al lies in the indication of ART. They have used a combination of prognostic factors as indication for ART and not only based on a single prognostic factor.

The fact is that although cervical cancer is theoretically preventable and one of the most curable human cancers, recurrences are unavoidable. Hence, the management of cervical carcinoma remains to be the most challenging in gynecologic oncology. The outcome of cervical carcinoma is related to 
certain prognostic factors. Many centers have emphasized the necessity of individualized treatment according to a combination of clinicopathologic factors. The score points assigned to each prognostic factor will give a better prediction of recurrence and produce better results in planning for adjuvant therapy. It is expected that by using scoring system in determining assignment of ART, the recurrence rate will be reduced.

In conclusion, ART in intermediate-risk group with a score $>120$ (based on Kartu Delgado) can reduce recurrence significantly. RFI for intermediate-risk group risk have a negative linear correlation with Kartu Delgado score. Instead of a single prognostic factor, we recommend the use of combination prognostic factors as an indication for ART.

\section{CONFLICT OF INTEREST}

No potential conflict of interest relevant to this article was reported.

\section{REFERENCES}

1. Sedlis A, Bundy BN, Rotman MZ et al. A randomized trial of pelvic radiation therapy versus no further therapy in selected patients with Stage IB carcinoma of the cervix after radical hysterectomy and pelvic lymphadenectomy: A Gynecologic Oncology Group study. Gynecol Oncol 1999; 73: 177-83.

2. Van der Velden J, Samlal R, Schilthuis MS et al. Limited role for adjuvant radiotherapy after the Wertheim/Okabayashi radical hysterectomy for cervical cancer confined to the cervix. Gynecol Oncol 1999; 75: 233-7.

3. Delgado G, Bundy B, Zaino R et al. Prospective surgicalpathological study of disease-free interval in patients with stage IB squamous cell carcinoma of the cervix: A Gynecologic Oncology Group study. Gynecol Oncol 1990; 38: 352-7.

4. Rushdan MN, Tay EH, Khoo-Tan HS et al. Tailoring the field and Indication of adjuvant pelvic radiation for patients with FIGO Stage IB lymph nodes-negative cervical carcinoma following radical surgery based on the GOG Score - A pilot study. Ann Acad Med Singapore 2004; 33: 467-72.

5. Pieterse QD, Trimbos JBMZ, Dijkman A et al. Postoperative radiation therapy improves prognosis in patients with adverse risk factors in localized, early-stage cervical cancer: a retrospective comparative study. Int J Gynecol Cancer 2006; 16: 1112-8.

6. Hirschowitz L, Ganesan R, Singh N et al. Standards and datasets for reporting cancers. Dataset for histological reporting of cervical neoplasia ( $3^{\text {rd }}$ edition). The Royal College of Pathologists 2011: 1-26.
7. Moon SH, Wu HG, Ha SW et al. Isolated full-thickness cervical stromal invasion warrants post-hysterectomy pelvic radiotherapy in FIGO stages IB-IIA uterine cervical carcinoma. Gynecol Oncol 2007; 104: 152-7.

8. Lee KBM, Lee JM, Park CY et al. What is the difference between squamous cell carcinoma and adenocarcinoma of the cervix? A matched case-control study. Int J Gynecol Cancer. 2006; 16: 1569-73.

9. Hellebrekers BWJ, Zwinderman AH, Kenter GG et al. Surgically-treated early cervical cancer: Prognostic factors and the significance of depth of tumor invasion. Int J Gynecol Cancer 1999; 9: 212-9.

10. Atahan IL, Yildiz F, Ozyar E et al. Radiotherapy in the adjuvant setting of cervical carcinoma: treatment, results, and prognostic factors. Int J Gynecol Cancer 2007; 17: 813-20.

11. Yeo RMC, Chia YN, Namuduri RPD et al. Tailoring adjuvant radiotherapy for stage IB-IIA node negative cervical carcinoma after radical hysterectomy and pelvic lymph node dissection using the GOG score. Gynecol Oncol 2011; 123: 225-9.

12. Rutledge TL, Kamelle SA, Tillmanns TD et al. A comparison of stages IB1 and IB2 cervical cancers treated with radical hysterectomy. Is size the real difference? Gynecol Oncol 2004; 95: 70-6.

13. Memarzadeh S, Natarajan S, Dandade DP et al. Lymphovascular and perineural invasion in the parametria: A prognostic factor for early-stage cervical cancer. Obstet Gynecol 2003; 102: 612-9.

14. Zaino R, Ward S, Delgado G et al. Histopathologic predictors of the behavior of surgically treated stage IB squamous cell carcinoma of the cervix: A Gynecologic Oncology Group study. Cancer 1992; 69: 1750-8.

15. Ayhan A, Al R, Baykal C et al. A comparison of prognoses of FIGO stage IB adenocarcinoma and squamous cell carcinoma. Int J Gynecol Cancer 2004; 14: 279-85.

16. Ng HT, Shyu SK, Chen YK et al. A scoring system in predicting recurrence of cervical cancer. Int J Gynecol Cancer 1992; 2: 75-8.

17. Monk BJ, Cha DS, Walker JL et al. Extent of disease as an indication for pelvic radiation following radical hysterectomy and bilateral pelvic lymph node dissection in the treatment of stage IB and IIA cervical carcinoma. Gynecol Oncol 1994; 54: 4-9.

18. Reis R, Frumovitz M, Milam MR et al. Adenosquamous carcinoma versus adenocarcinoma in early-stage cervical cancer patients undergoing radical hysterectomy: An outcomes analysis. Gynecol Oncol 2007; 107: 458-63.

19. Pieterse QD, Kenter GG, Eilers PHC et al. An individual prediction of the future (disease-free) survival of patients with a history of early-stage cervical cancer, multistate model. Int J Gynecol Cancer 2008; 18: 432-8.

20. Samlal R, Van der Velden J, Kate FJW et al. Surgical pathologic factors that predict recurrence in stage IB and IIA cervical carcinoma patients with negative pelvic lymph nodes. Cancer 1997; 80: 1234-40. 